\title{
Effectiveness of The Implementation of Supreme Court Regulation Number 1 Year 2016 on Divorce Settlement
}

\author{
Marzuki Marzuki1 ${ }^{*}$, Abidin Abidin 2, Hilal Malarangan ${ }^{3}$
}

${ }^{1}$ Islamic Family Law Department, Postgraduate, Institut Agama Islam Negeri Palu

2 Islamic Family Law Department, Postgraduate, Institut Agama Islam Negeri Palu

3 Islamic Family Law Department, Postgraduate, Institut Agama Islam Negeri Palu

\begin{abstract}
The focus of this research is the effectiveness of implementing Supreme Court Regulation No. 1 of 2016 concerning the Mediation Process in the Court in the settlement of divorce cases at the Donggala's Religious Court Class IB. The aim is to determine the implementation and effectiveness as well as the supporting and inhibiting factors for the implementation of the Supreme Court Regulation Number 1 of 2016 in the settlement of divorce cases. This research is a qualitative with a case study. The data were collected through observations, interviews, and documentation to the parties in the relevant research locations. The results of this study indicate that the Donggala Religious Court Class IB has implemented the practice of implementing mediation in accordance with the provisions of the Supreme Court Regulation Number 1 of 2016. However, the results of its implementation show that its effectiveness is still very small; this is evidenced by the high number of divorces each year. From the data on the number of divorces, it shows that divorce tends to increase which is dominated by divorce due to continuous disputes
\end{abstract}

ARTICLE

INFORMATION

Keywords:

Effectiveness, Suprame court, regulation, divorce settlement 


\section{Introduction}

The Supreme Court of the Republic of Indonesia, as the perpetrator of the highest judicial power in Indonesia, integrates the mediation process in the justice system in Indonesia. This can be seen in the issuance of the Supreme Court Circular No. 1 of 2002 concerning Empowerment of the Courts of the First Level to Implement Peaceful Institutions (Ex. Article 130 HIR/154 RBg.) on January 30, 2002. The decision was addressed to all District Courts and Religious Courts as an institution authorized to receive, examine, adjudicate and decide cases at the first level to empower peaceful efforts. ${ }^{1}$

Then, its position was perfected and enhanced by the issuance of Supreme Court Regulation No. 2 of 2003 concerning Mediation Procedures in Courts. This regulation was also revised with the issuance of Supreme Court Regulation Number 1 of 2008 concerning Mediation Procedures in Courts. However, this regulation, which is not yet 8 years old, is considered not yet optimal in meeting the need for a more efficient mediation implementation and able to increase the success of mediation in court. Thus, on February 3, 2016 the Regulation of the Supreme Court of the Republic of Indonesia Number 1 of 2016

1 Yunus, Haerunnisa, Rusli, Rusli, \& Abidin, Abidin. (2020). The Concept of A Marriage Agreement in the Compilation of Islamic Law International Journal Of Contemporary Islamic Law And Society, 2(2), 35-45. was issued concerning Mediation Procedures in Courts. ${ }^{2}$

The expectation of the Supreme Court of the Republic of Indonesia with the Regulation of the Supreme Court of the Republic of Indonesia Number 1 of 2016 will make a positive contribution to the implementation of mediation, as well as provide more space for the parties to carry out mediation as an alternative to peacefully resolving marital disputes according to the wishes of the parties by involving a mediator. This can be proven by the emergence of the most recent thing in this Supreme Court Regulation when compared to previous regulations on mediation, namely the existence of good faith and the legal consequences of parties who do not have good intentions in the mediation process. This is what the previous rules did not have.

This can be proven by the emergence of the most recent rule in this Supreme Court Regulation when compared to previous regulations on mediation, namely the existence of good faith and the legal consequences of parties who do not have good intentions in the mediation process. This rule is not contained in the previous rules.

In this regard, Thalis Noor Cahyadi, Manager of the Education and Training Center of the Indonesian Sharia Lawyers Association (APSI), stated that

The provisions of Article 7, 22 and 23 are markedly different from the

2 Sukaenah, Sukaenah, Rusli, Rusli, \& B, M. Taufan. (2020). The Effectiveness of Indonesia Supreme Court Regulation Number 1 Year 2016 Concerning Mediation of Marriage Disputes International Journal Of Contemporary Islamic Law And Society, 2(1), 63-80.

e-ISSN: 2715-4580 p-ISSN: $2715-8268$ 
provisions of the Supreme Court Regulation Number 1 of 2008, and in my opinion, this is where the essential spirit and indication of the effectiveness of the mediation process in resolving cases with good faith. With this, the mediation process will work effectively and efficiently. ${ }^{3}$

The presence of the Supreme Court Regulation Number 1 of 2016 puts more emphasis on the litigants taking a more intensive mediation process with good faith to make peace. The government, in this case, the Supreme Court, hopes that this will reduce the number of divorces that occur in Indonesia by offering peace efforts as a mutually beneficial solution for the conflicting parties. But in fact, if data on divorce rates, especially in the Religious Courts is presented, then the number is still quite high.

As stated by Anwar Saadi, Head of Sub-Directorate for the Head of the Urais and Binsyar Directorate of the Ministry of Religion,

The condition of family resilience in Indonesia until the end of 2016 has not shown any improvement if it is seen from the high divorce rate. The increase in the divorce rate reaches 16 - 20 percent. When compared to the number of marriages every year, which reaches 2,000,000 couples, it means an average of $10 \%$ ends in divorce. $^{4}$

3See this, http://www.hukumonline.com Accessd 1 September 2017.

${ }^{4}$ Anwar

Saadi, in http://www.gulalives.co/tingkat-perceraian-di-
The Indonesian Child Protection Commission, through the Deputy Chair, Rita Pranawati, highlighted the increasing divorce cases. She said,

Divorce in general continues to increase, Badilag data states that in 2016, the number of divorces reached 19.9 percent from the previous year, which reached 15 percent. Social media needs to be addressed wisely. ${ }^{5}$

Divorce is a big issue in every household, and also in Islamic text. ${ }^{6}$ The increasing divorce rate in Indonesia has been almost evenly distributed in recent years, and is a fact that cannot be denied. However, the divorce rate in this country is actually still fluctuating.

\section{Literature Review}

\subsection{Theory of Legal Effeciveness}

According to Soerjono Soekanto, as quoted by Nurul Hakim, ${ }^{7}$ the degree of effectiveness of a law is determined, among other things, by the level of community compliance with the law,

indonesia-termasuk-yang-tertinggi-di-dunia/. Accessed: 14 September 2014

5Sanusi, Kasus Perceraian Dipicu Medsos

KPAI Pikirkan Nasib Anak Anak
http://www.tribunnews.com/metropolitan/201 7/10/09/kasus-perceraian-dipicu-medsos-kpai pikirkan-nasib-anak-anak di akses tanggal, 25 Oktober 2017

${ }^{6}$ For the study of divorce from Quranic perspective, see Rusli Rusli, "Hermeneutical Reading of Țalāq," HUNAFA: Jurnal Studia Islamika 12, no. 2 (2016): 209-229.

${ }^{7}$ Nurul Hakim, Efektivitas Pelaksanaan Sistem Arbitrase dan Alternatif Penyelesaian Sengketa Dalam Hubungannya Dengan Lembaga Peradilan. In http:// badilag.net/data/ARTIKEL/Efektivitas.p df.

e-ISSN: $2715-4580$ p-ISSN: 2715-8268 
including law enforcers. There is an assumption that a high level of legal compliance is an indicator of the functioning of a legal system. And the functioning of the law is a sign that the law has achieved the purpose of the law, that is, trying to maintain and protect the community in social life.

The essence of law enforcement is that a harmonious relationship of values outlined in legal rules can manifest in the soul of society so as to create peace and orderliness. Wayne La Favre, as quoted by Soerjono Soekanto, ${ }^{8}$ considers that law enforcement as a process is essentially a discretion that involves making decisions that are not strictly regulated by the rule of law, but has an element of personal judgment.

Disruption to law enforcement may occur. This happens when there is a mismatch between values, rules, and patterns of behavior in society. So it can be said that law enforcement is not merely the implementation of the law, although in reality in Indonesia this tends to be the case. Then there can be disturbances of peace in social life if the implementation of the rules in the law turns out to be difficult for the community.

Based on the theory of legal effectiveness proposed by Soerjono Soekanto, the effectiveness of a law is determined by five factors. These factors have a neutral meaning, so that the positive or negative impact lies in the

\footnotetext{
8Soerjono Soekanto, Faktor-Faktor Yang Mempengaruhi Penegakan Hukum (Jakarta: Raja Grafindo Persada, 2007), 7.
}

content of these factors. These factors are as follows: ${ }^{9}$

\section{Legal Regulations}

This means a law in a material sense, namely a written regulation that is generally accepted and made by the Central and Regional Governments.

\section{Law enforcer}

The scope of the term "law enforcement" is very broad, because it includes those who are directly and indirectly involved in the field of law enforcement. In this paper, law enforcement includes not only law enforcement, but also peace maintenance. They are court legal officers within the Donggala Religious Court, both at the upper, middle, and lower strata, including judges, clerks, bailiffs, and other non-justicial employees.

3. Facilities that support law enforcement

Without certain facilities, it is impossible for law enforcement to run smoothly. These facilities include educated and skilled human resources, good organization, adequate equipment, sufficient finances, and so on. If these things are not fulfilled, it is impossible for law enforcement to achieve its objectives. ${ }^{10}$

4. Society

Society means the environment in which the law applies or is applied. Community legal compliance is strongly influenced by the previous three factors

\section{${ }^{9}$ Ibid, 8.}

${ }^{10} \mathrm{Ibid}, 10$. 
that include law, law enforcement, and facilities. Most people usually do not care about the rule of law that is applied, but they just want to get justice and legal certainty for the case they are facing.

Likewise, in the mediation process, both parties to the dispute have hope for law enforcement, namely the mediator, so that the dispute between them can be resolved properly. Therefore, the role of the mediator is very important in the course of the mediation process between the two parties. The ability of the mediator to know the values and rules that apply in a society is very important, so that the mediator can find a solution to the dispute, and not even add to the cloudiness of the atmosphere due to his ignorance of the values and rules that live in the community.

\section{Culture}

Culture is the result of work and creativity, based on human initiative in social life. Culture contains a system of values. As a system or subsystem of the social system, the law includes structure, substance, and culture. The structure includes the form of the system which includes the order of formal legal institutions, the relationship between these institutions, their rights and obligations, and so on.

The substance includes the contents of legal norms and their formulation, as well as the procedures for enforcing them, which apply to law enforcement and justice seekers. Legal culture basically includes the values that underlie applicable law, values which are abstract conceptions of what is considered good so that it can be guided and what is considered bad and should be avoided. These values reflect two extreme conditions that must be harmonized. This is the subject of discussion in this culture. In terms of mediation in religious courts, the seekers of justice there are Muslims, and Islamic values become guidelines because they have been rooted in the life of the Muslim community.

\subsection{Definition and Principles of Implementing Mediation in Courts}

The term "mediation" first appeared in the United States in the 1970s. Robert D. Benjamin, Director of Mediation and Conflict Management Service in St. Louis Missouri, stated that mediation was only known in the 1970s and was formally used in the Alternative Dispute Resolution (ADR) process in California. Chief Justice Warren Burger once held a conference questioning the effectiveness of the administration of the Court in Saint Paul in 1976. This year the term ADR was officially used by the American Bar Association (ABA) by establishing a special commission to resolve disputes. ${ }^{11}$

The word mediation is defined as "the process of involving a third party in the resolution of a dispute as an advisor" ${ }^{12}$ This definition contains three important elements

${ }^{11}$ Muhammad Saifullah, Sejarah dan Perkembangan Mediasi di Indonesia, dikutip oleh M. Mukhsin Jamil, Mengelola Konflik Membangun Damai, (Semarang: WMC IAIN WAlisongo Semarang, 2007), 211

12Tim Penyusun Kamus Pusat Pembinaan dan Pengembangan Bahasa, Kamus Besar Bahasa e-ISSN: 2715-4580 p-ISSN: 2715-8268 
1. Mediation is the process of resolving disputes that occur between two or more parties.

2. Party involved in dispute resolution is from outside the disputing parties.

3. The party involved in the dispute resolution acts as an advisor and does not have any authority in making decisions.

The word mediation, which means "being in the middle", refers to the role played by a third party as a mediator in carrying out their duties to mediate and resolve disputes between the parties. "Being in the middle" also means that the mediator must be in a neutral and impartial position in resolving disputes. $\mathrm{He}$ must be able to safeguard the interests of the disputing parties fairly and equally, so as to foster the trust of the disputing parties. ${ }^{13}$

Mediation is derived from English, which means a peaceful dispute resolution process that involves the assistance of a third party to provide a solution that is acceptable to the disputing parties. ${ }^{14}$ In the Regulation of the Supreme Court of the Republic of Indonesia Number 1 of 2016 concerning Mediation Procedures in Courts, mediation is a method of resolving disputes through a negotiation process to

Indonesia (Jakarta: Departemen Pendidikan dan Kebudayaan, 1988), 569.

13Syahrizal Abbas, Mediasi dalam Perspektif Hukum Syariah, Hukum Adat, dan Hukum Nasional, $1^{\text {st }}$ edition (Jakarta: Kencana Prenada Media, 2009), 1-2.

${ }^{14}$ B.N. Marbun, Kamus Hukum Indonesia, $1^{\text {st }}$ edition (Jakarta: Sinar Harapan, 2006), 168 obtain an agreement between the Parties with the assistance of a Mediator. 15

There are three aspects of mediation, 16

1. Aspects of urgency and motivation

In this case, the purpose of mediation is for the litigants to be at peace and not continue their case in court proceedings. If there are things that have been a problem, they must be resolved amicably by deliberation and consensus. The main goal of mediation is to achieve peace between the conflicting parties. The parties to a dispute or litigation are usually very difficult to reach an agreement when they meet by themselves. What have been frozen on the issues in dispute can usually become liquid, if someone brings them together to the meditator. So mediation is a means to bring together the parties so that the conflicting parties gain awareness of the importance of peace between them.

\section{Principle aspect}

Legally, mediation is stated in Article 3 paragraph (1) of the Supreme Court Regulation Number 1 of 2016 which requires every judge, mediator and parties to follow the procedure for resolving cases through mediation. Failure to follow the mediation procedure, according to this Supreme Court Regulation, will be considered a

\footnotetext{
${ }^{15}$ Supreme Court of the Republic of Indonesia, Supreme Court Regulation, Nomor 1 Year 2016 on the Procedures of Mediation in Court, Chapter I, Paraghraph 1 (1).

16Siddiki, Mediasi di Pengadilan dan Asas Peradilan Sederhana, Cepat, dan Biaya Ringan.in dari http://www.badilag.net/artikel/mediasi.pdf Accessed: 12 September 2017

e-ISSN: $2715-4580$ p-ISSN: $2715-8268$
} 
violation of the provisions of the laws and regulations governing mediation in the Court. If that has happened, then if a legal action is filed, the Court of Appeal (High Court or Supreme Court) with an interim decision orders the First Level Court to carry out the mediation process first.

\section{Aspect of substance}

Mediation is a proces that must be passed for every civil case that goes to court. The substance of mediation is a process that must be carried out seriously to achieve peace. Therefore, they are given separate time to carry out mediation before the case is examined. Mediation is not just to fulfill formal legal requirements, but is a serious effort that must be made by the parties concerned to achieve peace. Mediation is an attempt by the disputing parties to reconcile in the interests of the parties themselves. It is not in the interest of the Court or the judge, nor is it in the interest of the mediator. Thus, all costs arising from this mediation process are borne by the litigants.

\section{Methodology}

This study uses qualitative approach $^{17}$ investigating Islamic Law Perspectives on Settlement of inheritance disputes. This research was carried out in the Religious Court of Donggala, that has

17 Nurdin, N., \& Yusuf, K. (2020). Knowledge management lifecycle in Islamic bank: the case of syariah banks in Indonesia. International Journal of Knowledge Management Studies, 11(1), 59-80. https://doi.org/10.1504/ijkms.2020.105073 authority to deal with the cases of divorce.

Data were collected through observation, indepth interview, and written material ${ }^{18}$. Data analysis consists of several procedures: reduction and verification techniques with various data sources. ${ }^{19}$ The reduced data is then analyzed reflecting on theoretical concepts used in this study. ${ }^{20}$

\section{Results and Discussion}

\subsection{Effectiveness of Implementation of Supreme Court Regulation Number 1 Year 2016}

The purpose of the ratification of this Supreme Court Regulation is that it is hoped that mediation will be a method of peaceful dispute resolution that is appropriate, effective, and can open wider access to the parties to obtain a satisfactory and fair settlement. It is considered that Supreme Court Regulation No. 2008 concerning Mediation Procedures in Courts has not optimally met the need for a more

18 Nurdin, Nurdin. (2019). Knowledge Integration Strategy in Islamic Banks. In Almeida Helena \& Sequeira Bernardete (Eds.), The Role of Knowledge Transfer in Open Innovation (pp. 118138). Hershey, PA, USA: IGI Global.

19 Muslih, Imam, Nurdin, Nurdin, \& Marzuki, Marzuki. (2020). Effectiveness of Marriage Services Through Information System Management (SIMKAH) at Palu City Religious Court International Journal of Contemporary Islamic Law And Society, 2(1), 20-35.

${ }^{20}$ Iqbal, M., Rusli, R., \& Musyahidah, M. (2019). Management Strategies of Professional Zakat Funds for Mustahiq Family Welfare By Amil Zakat Body INTERNATIONAL JOURNAL OF CONTEMPORARY ISLAMIC LAW AND SOCIETY, 1(1), 39-51. 
efficient mediation implementation and is able to increase the success of mediation in court.

The report on the Empowerment of Peace Institutions at the Donggala Religious Court, Class IB, showed that the number of divorce cases that were submitted in 2016 was 308 cases, consisting of 226 cases of litigation and 82 divorced divorce cases. Of these cases that were mediated in 2016, 16 cases were successfully mediated, consisting of 10 cases of litigation and 6 cases of divorce. Meanwhile, the mediation that failed reached 292 cases. ${ }^{21}$

Likewise, in 2017, the number of divorce cases registered was 357 cases, consisting of 254 cases of litigation and 103 divorced divorce cases. Of this number, 20 cases were successfully mediated, consisting of 14 cases of litigation and 6 cases of divorce, while, 337 cases failed. ${ }^{22}$

Furthermore, in 2018, the number of divorce cases received by the Donggala Religious Court Class IB decreased if compared to the previous year. In that year, the number of registered divorce cases was 312 cases, which included 232 cases of litigation and 80 divorces. Those that were successfully mediated amounted to 19 cases consisting of 13 cases of litigation and 6 cases of divorce, while those that failed reached 293 cases.

The data shows that since the enactment of the Supreme Court

${ }^{21}$ See the report of the Empowerment of Peace Institutions at the Donggala Religious Court Class IB from 2016 - 2018.

22Ibid
Regulation Number 1 of 2016 at the Donggala Religious Court, the number of divorce cases that have been successfully mediated and those that were not is very disproportionate. According to the five mediator judges and junior law clerks at the Donggala Religious Court Class IB, the implementation of Supreme Court Regulation Number 1 of 2016 concerning Mediation Procedures in Courts, especially in divorce cases at the Class IB Donggala Religious Court, went well. ${ }^{23}$

\subsection{Factors that support and inhibit the Implementation of Supreme Court Regulation Number 1 Year 2016}

The success or failure of the implementation of mediation in divorce case in court is strongly influenced by the supporting and inhibiting factors during the mediation process. The following are the factors that support the success of mediation at the Donggala Religious Court Class IB

1) Mediator expertise

A mediator who is good at managing conflict ${ }^{24}$ and communication so that he can seek a common ground between the parties will easily encourage peace. Therefore, the ability of a mediator will affect the success of mediation. It also takes the foresight of the mediator to reveal whether the problems between the parties and the discretion of the mediator

${ }^{23}$ Summary of interview with St. Hasmah, Amar Ma'ruf, Ruhana Faried and Rustam are all Mediator Judges on 3 June 2019.

${ }^{24}$ For more study, see Rusli Rusli, "The Role of Musalahah in Conflict Resolution: A Historical Perspective," Hunafa: Jurnal Studia Islamika 10, no. 2 (December 15, 2013): 203-220.

e-ISSN: $2715-4580$

p-ISSN: 2715-8268 
in providing solutions, so that the parties successfully resolve the problem peacefully and well. ${ }^{25}$

2) The good intention of the parties to make peace

During the mediation process, the mediator tries to reconcile the parties. However, no matter how good the efforts made by the mediator in reconciling will not succeed if it is not supported by the good intention of the conflicting parties to reconcile, and their awareness of shortcomings so that they can forgive each other and start living in harmony again. ${ }^{26}$ This is the factor that drives the success of the mediation process in the Court.

3) Social and psychological factors of the parties

The social conditions of the parties determine the success of mediation. For example, a woman who is suing her husband for divorce will think about sustenance for herself and her children. For women who do not have jobs or adequate income, but are worried about shortages, they will think again about filing for divorce from their husbands. However, for women who already have a steady job and sufficient income, the tendency to separate from their husbands is stronger. Likewise, the sociological conditions of the children resulting from

${ }^{25}$ Interview with St. Hasmah, Mediator Judge, Dongggala's Religious Court Class IB (3 June 2019).

${ }^{26}$ Interview with Amar Ma'ruf, Mediator Judge, Dongggala's Religious Court Class IB (3 June 2019). their marriage are taken into consideration to stay together.

The psychological condition of the parties can affect the success of mediation. A person who wants to separate from his partner must have felt uncomfortable even physical and psychological suffering that lasted a long time. The greater the pressure on a person, the greater the desire to separate from his partner. Internal factors from the parties, especially psychological factors support the success of mediation. ${ }^{27}$

4) Behavioral and spiritual factors of the parties

Mistakes or less serious causes of disagreement can make it easier for the mediator to seek peace, such as shortly emotions that cannot be suppressed. However, bad behavior can make one of the parties unwilling to get back together, because if they return to the marriage bond, their life will get worst. Likewise, the spiritual level of one's religious understanding affects the success of mediation. The better the understanding of each party's religion, the easier it will be for the mediator in the process of reconciling the two parties.

The factors that hinder the success of mediation in divorce cases at the Donggala Religious Court Class IB are as follows:

a. Strong desire of the parties to divorce

At the time before the mediation was carried out, one of the parties or

\footnotetext{
27Interview with Rustam Hakim, Mediator Judge, Dongggala's Religious Court Class IB (3 June 2019).
}

e-ISSN: $2715-4580$ p-ISSN: 2715-8268 
both had agreed and had a very strong desire to divorce. Their arrival to the Donggala's Religious Court Class IB occurred due to the unsuccessful efforts to make peace between them involving the families of each party. So this often makes it difficult for mediators to seek peace because they have insisted on getting a divorce as soon as possible. ${ }^{28}$

In general, almost all plaintiffs who file their lawsuits to the Religious Courts are the point of culmination or climax of the peace efforts that failed in the family environment. So, mediation efforts are certainly difficult to do because they insisted on divorce from the start, so they register the case to the religious court to get a divorce decision, not to be reconciled.

\section{b. Prolonged dispute}

Prolonged disputes that occur between the parties caused the mediation to fail. The parties cannot suppress their emotions, so they can no longer accept inputs from the mediator. In fact, it often happens that the applicant/plaintiff is unable to forgive the respondent/defendant, so that it is difficult to get together again. ${ }^{29}$ This can also be proven by the data that the dominant factors causing divorce are continuous disputes, which reached $60 \%$ of all other factors causing divorce.

c. Psychological factors of the parties who are victims

${ }^{28}$ Interview with Ruhana Faried, Rustam dan Amar Ma'ruf, Mediator Judges, Dongggala's Religious Court Class IB (3 June 2019).

${ }^{29}$ Interview with Ruhana Faried, Rustam dan Amar Ma'ruf, Mediator Judges, Dongggala's Religious Court Class IB (3 June 2019).
The disappointment towards their partner often leads to a sense of hopelessness in marital relationship. So there is no other choice but to end the marriage. ${ }^{30}$ This is felt by the party who is the victim of the dispute, usually the wife who feels it the most.

d. The presence or involvement of third parties

The presence of third parties also contributed to the failure of peace efforts. ${ }^{31}$ The third party in question can include parents, family, or other parties who provide support for divorce. The third party in question is specifically the family. Initially, each family gave advice or mediated the conflicting parties, but when the two failed to be reconciled, then the respective families changed, from initially advising to get along to being confrontational in defending each of their families. ${ }^{32}$

\section{Conclusions}

The paper concludes that the Supreme Court regulation Number 1 of 2016 concerning the Mediation Process in the Court has been implemented since 2016 at the Donggala's Religious Court Class IB, in accordance with the provisions in the regulation, but still needs some improvements and improvements, especially on training for

\section{${ }^{30} \mathrm{Ibid}$,}

${ }^{31}$ St. Hasmah, Rustam hakim mediator Pengadilan Agama Donggala Kelas IB tanggal 3 Juni 2019

32 See Rusli Rusli, "The Role of Family in Preventing Social Conflict in Society From Islamic Perspectives," HUNAFA: Jurnal Studia Islamika 17, no. 1 (2020): 108-122.

e-ISSN: $2715-4580$ p-ISSN: 2715-8268 
mediator judges and adding existing facilities.

Based on the analysis of the effectiveness of its implementation specifically in the settlement of divorce cases, it can be concluded that the Supreme Court Regulation in the Donggala Religious Court Class IB has not been effective even though it has increased every year. This is based on the data on the failure of mediation in divorce cases, which is still very high, compared to the very low success rate.

\section{REFERENCES}

Amriani, Nurnaningsih. Mediasi Alternatif Penyelesaian Sengketa Di Pengadilan. Jakarta: Rajawali Press, 2012.

Ali, Achmad. Sosiologi Hukum: Kajian Empiris Terhadap Pengadilan, $1^{\text {st }}$ edition. Jakarta: Badan Penerbit IBLAM, 2004.

Aliyah, Samir. Sistem Pemerintahan Peradilan dan Adat dalam Islam. Jakarta: Khalifa, 2004.

Abdurahman, Muslan. Sosiologi dan Penelitian Hukum. Malang: UMM Press, 2009.

Ashiddiqie, Jimly. Gagasan Kedaulatan Rakyat dalam Konstitusi dan Pelaksanaannya di Indonesia. Ichtiar Baru van Hoeve, Jakarta, 1994.

Ashiddiqie, Jimly. "Cita Negara Hukum Indonesia Kontemporer" Sumber Cahaya. No. 25 Tahun IX Mei 2004.

Ali, Zaenuddin. Metode Penelitian Hukum. Jakarta: Sinar Garfika, 2011.

Abbas, Syahrizal. Mediasi: Dalam Perspektif Hukum Syariah, Hukum Adat, dan Hukum Nasional, $1^{\text {st }}$ edition. Jakarta: Kencana Prenada Media, 2009.

Amrullah, Abdul Malik Abdulkarim, Tafsir Al-Azhar, vol. 2. $5^{\text {th }}$ edition. Singapura: Pustaka Nasional Pte Ltd, 2003.

Arto Mukti. Praktik Perkara Perdata pada

Pengadilan Agama. Yogyakarta:

Pustaka Pelajar, 2003.

Asqalani, Ibnu Hajar. Bulugul Maram dan

Dalil-Dalil Hukum. Trans. Jakarta:

Gema Insani, 2013.

Bukhari, Muhammad bin Ismail, Shahih al-Bukhari. Vol.3. Cairo: Dar alHadis, 2000.

Busti, Muhammad bin Hibban bin Ahmad Abu Hatim al-Tamimi. Shahih Ibnu Hibban bi Tartibi Ibnu Bilban. Vol. 11. $2^{\text {nd }}$ edition. Beirut: Muassasah al-Risalah, 1993.

Dimasyqi, Abu al-Fida Ismail bin Umar bin Katsir al-Qurasy. Tafsir alQuran al-Azhim, Vol.2. 2nd Edition. Riyad: Dar Thayibah, 1999.

Garner, Bryan A. Ed, Black"s Law Dictionary, 8th edition. USA: West, 2004.

Head, John W, Pengantar Umum Hukum Ekonomi. Jakarta: Proyek ELIPS, 1997.

Hakim, Nurul, Efektivitas Pelaksanaan Sistem Arbitrase dan Alternatif Penyelesaian Sengketa Dalam Hubungannya Dengan Lembaga Peradilan.

http://badilag.net/data/ARTIKE

L/efektifitas.pdf (10 Oktober 2017).

Iqbal, Muhammad, Rusli, Rusli, \& Musyahidah, Musyahidah. (2019). Management Strategies of Professional Zakat Funds for e-ISSN: 2715-4580 p-ISSN: 2715-8268 
Mustahiq Family Welfare By Amil Zakat Body International Journal of Contemporary Islamic Law And Society, 1(1), 39-51.

Mujahidin, Ahmad, Pembaharuan Hukum Acara Peradilan Agama. Bogor: Ghalia Indonesia, 2012.

Margono, S, Metodologi Penelitian Pendidikan, $2^{\text {nd }}$ edition. Jakarta : Rineka Cipta, 2000.

Mileong, Lexy J, Metode Penelitian Kualitatif, Edisi Revisi. Bandung: PT. Rosda Karya, 2006.

Manzur, Ibnu. Lisan al-Arab. vol. 2 Beirut: Dar Sadir,1990.

Marbun, B.N. "Negara Hukum dan Kekuasaan Kehakiman" Jurnal Hukum Ius Quia Iustum. No. 9. Vol. 4, 1997.

Muslih, Imam, Nurdin, Nurdin, \& Marzuki, Marzuki. (2020). Effectiveness of Marriage Services Through Information System Management (SIMKAH) at Palu City Religious Court INTERNATIONAL JOURNAL OF CONTEMPORARY ISLAMIC LAW AND SOCIETY, 2(1), 20-35.

Notohamidjojo O., Makna Negara Hukum, Jakarta: Badan Penerbit Kristen, 1970.

Nahrudin, "350 Janda Di Donggala Dan Sigi," in http:// sultengraya.com/2016/10/ 27/350-janda-di-donggala-dansigi/

Noeh, Zaini Ahmad. Sejarah Singkat Peradilan Agama Islam di Indonesia. Surabaya: Bina Ilmu, 1980.

Nurdin, Nurdin. (2019). Knowledge Integration Strategy in Islamic Banks. In Almeida Helena \&
Sequeira Bernardete (Eds.), The Role of Knowledge Transfer in Open Innovation (pp. 118-138). Hershey, PA, USA: IGI Global.

Nurdin, Nurdin, \& Yusuf, Khaeruddin. (2020). Knowledge management lifecycle in Islamic bank: the case of syariah banks in Indonesia. International Journal of Knowledge Management Studies, 11(1), 59-80. doi: $10.1504 / \mathrm{ijkms.2020.105073}$

Nurhayati, Penyelesaian Sengketa Dalam Hukum Ekonomi Islam, Jurnal Hukum Ekonomi Syariah Sekolah Tinggi Agama Islam DDI Maros, Vol. 3, Number 1, January-June, 2019.

Puspita Dewi, Eva Meizara dan Basti. "Konflik Perkawinan dan Model Penyelesaian Konflik Pada Pasangan Suami Istri" Jurnal Psikologi. Vol 2, No. 1, December 2008.

Rifa'i, Muhammad Nasih, Ringkasan Tafsir Ibnu Katsir, Vol. 1. Jakarta: Gema Insani, 2012.

Rahardjo, Satjipto. Ilmu Hukum, Bandung: Citra Adytia Bakti, 2000.

Rusli Rusli, "The Role of Musalahah in Conflict Resolution: A Historical Perspective," Hunafa: Jurnal Studia Islamika 10, no. 2 (December 15, 2013): 203-220.

Rusli Rusli, "Hermeneutical Reading of TTalāq," HUNAFA: Jurnal Studia Islamika 12, no. 2 (2016): 209-229.

Rusli Rusli, "The Role of Family in Preventing Social Conflict in Society From Islamic Perspectives," HUNAFA: Jurnal Studia Islamika 17, no. 1 (2020): 108-122. 
Iqbal, Muhammad, Rusli, Rusli, \& Musyahidah, Musyahidah. (2019). Management Strategies of Professional Zakat Funds for Mustahiq Family Welfare By Amil Zakat Body INTERNATIONAL JOURNAL OF CONTEMPORARY ISLAMIC LAW AND SOCIETY, $1(1), 39-51$.

Shidleqy, T.M. Hasbi, Peradilan dan Acara Islam, Bandung: al-Ma'arif, tt

Sijistani, Abu Dawud Sulaiman bin alAsy"eats, Sunan Abu Dawud. Juz 2, Beirut: Dar al Kutub al-,,Arabi, t.t

Sururie, Ramdani Wahyu. Problem Penyelesaian Sengketa Perkawinan Melalui Mediasi Dalam Sistem Peradilan Agama, Makalah, 2014

Susilo, Budi. Prosedur Gugatan Cerai, Yogyakarta, Pustaka Yustisia, 2007

Spencer, David and Michael Borgan. Mediation Law and Practice, Cambridge: Cambridge University Press, 2006.

Siddiki, Mediasi di Pengadilan dan Asas Peradilan Sederhana, Cepat dan Biaya Ringan, hal. 1. Artikel diakses dari www.badilag.net diakses 21 September 2017.

Soekanto, Soerjono. Faktor-Faktor Yang Mempengaruhi Penegakan Hukum, Jakarta: Raja Grafindo Persada, 2007.

Soekanto, Soerjono. Penelitian Hukum Normatif. Jakarta: Raja Grafindo, 2003.

Sugiyono, Metode Penelitian Pendidikan Pendekatan Kuantitatif, Kualitatif dan RD, Cet XVIII; Bandung; Alfabeta, 2013

Saifullah, Muhammad, Efektifitas Mediasi Dalam Penyelesaian Perkara
Perceraian di Pengadilan Agama Jawa Tengah, Jurnal Al Ahkam ISSN 0852-4603 Volume 25 Nomor 2 Oktober 2015.

Sukaenah, Sukaenah, Rusli, Rusli, \& B, M. Taufan. (2020). The Effectiveness of Indonesia Supreme Court Regulation Number 1 Year 2016 Concerning Mediation of Marriage Disputes International Journal Of Contemporary Islamic Law And Society, 2(1), 63-80.

Utrecht, Pengantar Hukum Administrasi Negara Indonesia, Jakarta: Ichtiar, 1962

Witanto, D.Y. Hukum Acara Mediasi: Dalam Perkara Perdata di Lingkungan Peradilan Umum dan Peradilan Agama Menurut Peraturan Mahkamah Agung No. 1 Tahun 2008 Tentang Prosedur Mediasi di Pengadilan, cet.I, Bandung: Alfabeta, 2010.

Widodo, Kamus Ilmiah Populer Dilengkapi EYD dan Pembentukan Istilah, Yogyakarta; Absolut, 2002.

Yunus, Haerunnisa, Rusli, Rusli, \& Abidin, Abidin. (2020). The Concept of A Marriage Agreement in the Compilation of Islamic Law International Journal Of Contemporary Islamic Law And Society, 2(2), 35-45. 